\title{
PENGARUH DIGITAL MARKETINGTERHADAP ORGANIZATIONAL PERFORMANCE DENGANINTELLECTUALCAPITAL DANPERCEIVED QUALITY SEBAGAI VARIABEL INTERVENING PADA INDUSTRI HOTEL BINTANG EMPAT DI JAWA TIMUR
}

\author{
Daniel Laksana ${ }^{1}$ and Diah Dharmayanti ${ }^{2}$ \\ ${ }^{1,2}$ Program Studi Manajemen Pemasaran, Fakultas Ekonomi, Universitas Kristen Petra \\ Jl. Siwalankerto 121-131, Surabaya 60236 \\ Email: m36413065@john.petra.ac.id1, dharmayanti@peter.petra.ac.id ${ }^{2}$
}

\begin{abstract}
Abstrak: Pertumbuhan pariwisata di Indonesia terutama di kota besar seperti Surabaya mengalami pertumbuhan yang signifikan. Salah satunya yitu industri perhotelan. Dengan adanya teknologi yang berkembang pesat, media digital digunakan dalam segala aktivitas pemasaran di industri perhotelan ini dalam rangka meningkatkan performa organisasi dari perusahaan. Penelitian ini bertujuan untuk menganalisa Pengaruh Digital Marketing terhadap Organizational Performance dengan Intellectual Capital dan Perceived Quality sebagai Variable Intervening pada Industri Hotel Bintang Empat di Jawa Timur. Terdapat 120 responden karyawan hotel bintang empat di Jawa Timur yang menjadi sampel. Teknik analisa yang digunakan adalah teknik analisis kuantitatif dengan metode path analysis.
\end{abstract}

Kata kunci: Digital Marketing, intellectual capital, perceived quality, organizational performance.

\begin{abstract}
Growth of tourism in Indonesia especially in big cities like Surabaya experienced a significant growth. One of them is the hospitality industry. With the rapidly evolving technology, digital media is used in all marketing activities in the hospitality industry in order to improve the organization's performance from the company. This study aims to analyze the Influence of Digital Marketing on Organizational Performance with Intellectual Capital and Perceived Quality as Intervening Variable in Four Star Hotel Industry in East Java. This study was conducted by distributing questionnaires to 120 respondents of four-star hotel employees in East Java. Analysis technique used is quantitative analysis technique with path analysis method.
\end{abstract}

Keywords: Digital Marketing, intellectual capital, perceived quality, organizational performanc.

\section{PENDAHULUAN}

Pertumbuhan ekonomi di Indonesia selama beberapa tahun terakhir ini terus mengalami peningkatan.Secara kumulatif, pertumbuhan ekonomi Indonesia sepanjang 2016 tercatat sebesar 5,02 persen, meningkat dibandingkan tahun 2015 sebesar 4,88 persen dan lebih tinggi juga dibanding 2014 sebesar 5,01 persen (Badan Pusat Statistik, 2017). Pertumbuhan ini di hasilkan dari berbagai sektor perindustrian di Indonesia.Salah satunya adalah dari industri pariwisata dan perhotelan.

Bisa dikatakan bahwa perkembangan bisnis pariwisata dan perhotelan di Indonesia mengalami peningkatan yang cukup signifikan. Hal ini bisa dilihat berdasarkan meningkatnya jumlah kunjungan wisatawan di Indonesia dan pertumbuhan industri pariwisata termasuk bertumbuhnya jumlah hotel di Indonesia. Tumbuhnya kelas ekonomi menengah ikut membawa dampak positif terhadap statistik wisatawan di Indonesia. Riset Frost \& Sullivan pada tahun 2011 menunjukkan pengeluaran yang dikeluarkan orang Indonesia untuk travelling bernilai US\$ 6,4 miliar. Pada tahun 2030, angka tersebut diperkirakan tumbuh hampir empat kali lipat, mencapai US\$ 23,7 miliar.

Para wisatawan pada era ini didominasi oleh mereka yang berusia muda, fasih terhadap internet, dan menginginkan segalanya serba cepat. Karakteristik inilah yang dipandang sebagai potensi besar oleh sejumlah pebisnis di Indonesia.Seiring berkembangnya zaman, tingkat persaingan yang semakin tinggi pada industri perhotelan memaksa pelaku bisnis perhotelan meningkatkan kualitas pelayanannya untuk menghadapi pesaing. Menurut data dari Kemenpar, tingkat penghunian kamar (TPK) hotel berbintang di Jawa Timur mencapai angka yang paling tinggi yaitu 58,14 pada tahun 2016. Selain itu, rata-rata TPK hotel di merupakan yang tertinggi di Pulau Jawa melebihi DKI Jakarta dan Jawa Barat. Hal ini menandakan adanya prospek bisnis yang baik dalam industri hotel khususnya di daerah Jawa Timur.Kemampuan perusahaan didalam memanfaatkan digital marketing secara optimal diharapkan mampu meningkatkan performa dari perusahaan, terutama dalam industri perhotelan dimana dalam hal ini kita mengenalnya sebagai organizational performance atau performa organisasi. Organizational 
performance adalah aspek kunci dalam banyak penelitian dalam literatur manajemen karena memainkan peran penting dalam mengembangkan, melaksanakan, dan memantau rencana strategis dan menentukan arah masa depan.

Dalam mencapai organizational performance dengan standar yang tinggi, hal ini tentunya dipengaruhi juga oleh modal kapital dan persepsi kualitas. Melihat fakta bahwa saat ini usia produktif para pekerja didominasi oleh mereka yang sangat cakap teknologi, maka penggunaan digital marketing dalam segala aspek akan sangat mempengaruhi intellectual capital dari perusahaan. Perlu disadari 50-90\% nilai perusahaan ditentukan oleh intellectual capital dan bukan ditentukan oleh aset tetap dari perusahaan. Perkembangan ekonomi baru didorong oleh informasi dan pengetahuan yang menyebabkan meningkatnya perhatian pada intellectual capital. Oleh karena itu, Intellectual capital menjadi komponen penting yang harus dikelola oleh suatu organisasi. Intellectual capital didefinisikan sebagai jumlah dari aset tidak berwujud yang terkait dengan pengetahuan tentang perusahaan yang telah diformalkan, ditangkap, dan dimanfaatkan untuk menghasilkan aset bernilai lebih tinggi dan untuk menciptakan keunggulan kompetitif.

Persepsi kualitas atau biasa disebut perceived quality juga merupakan variabel yang dipengaruhi oleh digital marketing dan menjadi perantara didalam mencapai organizational performance yang baik. Menurut David A. Aaker (2003), perceived quality merupakan persepsi konsumen terhadap keseluruhan kualitas atau keunggulan suatu produk atau jasa layanan yang sama dengan maksud yang diharapkannya.

Melihat pengaruh antara digital marketing terhadap intellectual capitaldan perceived qualitydalam meningkatkan organizational performance pada sektor perhotelan, serta melihat persaingan yang ketat pada industri perhotelan di Jawa Timur, maka merupakan sebuah penelitian yang menarik untuk melihat bagaimana pengaruh antar variabel diatas dengan memilih objek penelitian hotel bintang empat di Jawa Timur karena diyakini bahwa industri perhotelan harus memiliki strategi yang menarik untuk dapat bersaing dengan hotel lainnya serta dalam rangka meningkatkan kinerja perusahaan. Berdasarkan latar belakang diatas, penulis ingin melakukan penelitian terhadap pengaruh Digital marketing terhadap organizational performance melalui intellectual capital dan perceived quality pada industri hotel bintang empat di Jawa Timur. Penulis berharap dapat memberikan gambaran yang jelas bahwa digital marketing yang di dukung dengan adanya intellectual capital dan perceived quality dapat meningkatkan organizational performance dari indsutri hotel bintang empat di Jawa Timur.

\section{LANDASAN TEORI}

\section{Digital Marketing}

Marketing Institute Digital mendefinisikan pemasaran digital sebagai penggunaan teknologi digital untuk menciptakan komunikasi yang terintegrasi, sasaran dan terukur yang membantu untuk memperoleh dan mempertahankan pelanggan sambil membangun hubungan yang lebih mendalam dengan mereka. Pemasaran digital meliputi pemasaran langsung, yang memperlakukan pelanggan sebagai individu dan mendefinisikan mereka tidak hanya oleh karakteristik individu tetapi juga oleh bagaimana mereka berperilaku, dan pemasaran interaktif, yang memiliki kemampuan untuk mengatasi individu dan kemampuan untuk mengumpulkan dan mengingat respon bahwa individu.

Eun Young Kim (2002) menetapkan empat dimensi Digital Marketing yang dapat disebutkan sebagai berikut:

a) Cost/Transaction,

b) Interactive

c) Incentive Program

d) Site Design

\section{Intellectual Capital}

Intellectual capital dapat dipandang sebagai pengetahuan dalam pembentukan, kekayaan intelektual dan pengalaman yang dapat digunakan untuk menciptakan kekayaan (Stewart, 1997). Intellectual capital juga dapat didefinisikan sebagai investasi dari sumber daya tidak berwujud dengan mengalokasikan sumber daya organisasi yang tidak berwujud dalam bentuk fisik.Dalam hal ini, sumber daya organisasi, seperti keahlian, pengetahuan, dan kemampuan organisasi perusahaan tidak dapat dinilai secara langsung.

Intellectual Capital memiliki peran yang sangat penting dan strategis di dalam mengukur sumber daya manusia di dalamnya.Intellectual Capital dikategorikan sebagai aset tidak berwujud (intangible asset). Intellectual Capital merupakan Intellectual Capital asset yang sangat penting di era informasi dan pengetahuan, dimana Intellectual Capital mengacu kepada pengetahuan dan kemampuan yang dimiliki oleh suatu kolektivitas sosial, seperti organisasi komunitas intelektual atau praktek profesional. Intellectual Capital adalah pengetahuan, namun tidak semua pengetahuan termasuk di dalam Intellectual Capital. 
Dari beberapa definisi beberapa penelitian dalam mengukur intellectual capital, dibedakan menjadi 3 komponen yaitu human capital, structural capital, dan customer capital (Bontis, 2008). Ketiga komponen tersebut saling membantu dalam membantu menciptakan nilai dan saling memberikan manfaat timbal balik.

\section{Perceived Quality}

Perceived quality dapat didefinisikan sebagai penilaian (persepsi) konsumen terhadap keunggulan suatu produk secara keseluruhan. Persepsi kualitas sendiri melibatkan perbedaan antara besarnya manfaat yang diterima dan pengorbanan yang diberikan. Aaker (2003) mengemukakan bahwa perceived quality sebagai persepsi pelanggan terhadap seluruh kualitas atau keunggulan sebuah produk atau jasa layanan sehubungan dengan maksud yang diharapkan.

Perceived quality yang tinggi menunjukkan bahwa konsumen telah menemukan perbedaan dan kelebihan produk tersebut dengan produk sejenis setelah melalui jangka waktu yang lama.Perceived quality adalah komponen dari nilai merk oleh karena itu perceived quality yang tinggi akan mendorong konsumen untuk lebih memilih merk tersebut dibandingkan pesaing. Berbagai kriteria yang berbeda perlu mendasari dalam penilaian suatu perceived quality, dan yang terpenting terpenting adalah kepuasan yang diperoleh oleh pelanggan tidak sama dengan perceived quality.

Sebuah produk dinyatakan berkualitas jika dapat memenuhi harapan pelanggan sesuai dengan dimensidimensi yang ada. Menurut pendapat Russel (1993) ada 8 dimensi dalam menentukan kualitas sebuah perusahaan:
1. Performance
2. Durability
3. Serviceability
4. Aesthetics
5. Perceived.
6. Conformance
7. Reliability
8. Features

\section{Organizational Performance}

Bernardin dan Russel (dalam Ruky, 2002) mendefinisikan kinerja sebagai catatan tentang hasil-hasil yang diperoleh dari fungsi-fungsi pekerjaan tertentu atau kegiatan selama kurun waktu tertentu.Payaman Simanjuntak (2005) mendefinisikan kinerja sebagai tingkat pecapaian hasil atas pelaksanaan tugas tertentu dan kinerja merupakan hasil yang dicapai dari perilaku anggota organisasi. Maka dari itu, Kinerja perusahaan merupakan tingkat pencapaian hasil dalam rangka mewujudkan tujuan perusahaan dan keseluruhan kegiatan yang dilakukan untuk meningkatkan performa perusahaan atau organisasi.

Bontis (2008) menetapkan enam elemen Organizational Performance. Enam elemen tersebut yang membantu keberhasilan usaha sebagai variabel dependen. Enam elemen tersebut yang dikenal sebagai berikut:

1. Role Set

2. Role Script

3. Role Congruence

4. Role Expansion

5. Role Discrepancy

6. Role Conflict

\section{Model Penelitian}

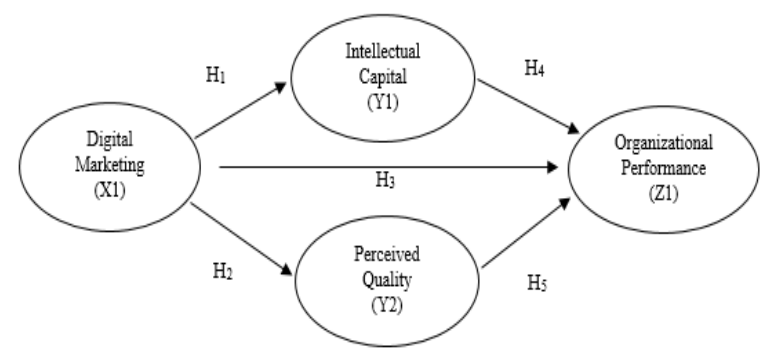

Gambar 1. Model Penelitian

Hipotesa

H1: Digital Marketing berpengaruh positif terhadap Intellectual Capital

H2: Digital Marketing berpengaruh positif terhadap Perceived Quality

H3: Digital Marketing berpengaruh positif terhadap Organizational Performance

H4: Intellectual Capital berpengaruh positif terhadap Organizational Performance

H5: Perceived Quality berpengaruh positif terhadap Organizational Performance

\section{METODOLOGI PENELITIAN}

\section{Populasi}

Populasi adalah gabungan seluruh elemen yang memiliki serangkaian karakteristik serupa, yang mencakup semesta untuk kepentingan masalah riset pemasaran (Malhotra, 2004). Pendapat lainnya mengatakan bahwa populasi adalah wilayah generalisasi yang terdiri dari obyek atau subyek yang mempunyai kualitas dan karakteristik tertentu yang diterapkan oleh peneliti untuk dipelajari dan kemudian ditarik 
kesimpulannya (Sugiyono, 2009). Populasi dalam penelitian ini adalah internal dari industri hotel bintang empat di Jawa Timur.

\section{Sampel}

Sampel adalah sebagian dari populasi yang ditetapkan oleh peneliti (Sugiyono, 2009). Malhotra (2007) juga menambahkan bahwa sampel adalah kelompok dari unsur-unsur populasi yang dipilih untuk berpartisipasi dalam penelitian. Dalam melakukan survei tidak perlu untuk meneliti semua individu dalam populasi karena akan banyak biaya dan waktu. Namun, syarat utama sampel yang baik yaitu apabila sampel yang diambil mewakili ciri dan karakteristik populasi (representatif) dengan bias yang kecil (Sugiyono, 2009).

\section{Definisi Operasional Variable}

\section{Digital Marketing (X1)}

a. Transaction/Cost

Merupakan salah satu teknik promosi yang memliki tingkat efisiensi yang tinggi sehingga dapat menekan biaya dan waktu transaksi.

b. Incentive Program

Program-program yang menarik tentu menjadi keunggulan dalam setiap promosi yang dilakukan. Program-program ini juga diharapkan agar dapat memberikan nilai yang lebih kepada perusahaan.

c. Site Design

Merupakan tampilan menarik dalam media digital marketing yang dapat memberikan nilai positif bagi perusahaan.

d. Interactive

Merupakan hubungan dua arah antara pihak perusahaan dengan konsumen yang dapat memberikan info dan dapat diterima dengan baik dan jelas.

\section{Intellectual Capital (Y1)}

\section{a. Human Capital}

Merupakan sekumpulan aset tidak berwujud yang mencerminkan kemampuan dalam perusahaan berupa pengetahuan yang dimiliki dalam bentuk pekerja profesional mereka

b. Structural Capital

Merupakan struktur perusahaan yang mendukung usaha dari pekerja pada perusahaan tersebut untuk dapat menghasilkan kinerja intelektual yang optimal.

c. Customer Capital

Adalah hubungan antara perusahaan dengan mitra kerja dan pihak eksternal perusahaan baik itu berasal dari pelanggan, pemasok, maupun hubungan antara perusahaan dengan pemerintah atau masyarakat sekitar.

3. Perceived Quality (Y2)

a. Features yaitu nilai tambah atau inovasi baru yang ditambahkan pada fitur dasar. Sehingga dapat sesuai dengan kebutuhan pelanggan.

b. Reliability yaitu kemungkinan produk atau jasa mampu memenuhi kebutuhan atau keinginan pelanggan sehingga mampu memenuhi citacita pelanggan.

c. Conformance yaitu kesesuaian kinerja dan mutu produk dengan janji yang diberikan oleh perusahaan kepada konsumen.

d. Durability yaitu berhubungan dengan jangka waktu atau masa guna barang atau jasa yang digunakan dalam satu periode tertentu.

e. Serviceability yaitu kemudahan mendapatkan pelayanan dan informasi yang dibutuhkan oleh pelanggan.

f. Aesthetics yakni menyangkut dengan keindahan atau penampilan dan penyajian pelayanan atau jasa.

4. Organizational Performance (Z1)

a. Role Set yaitu peran set internal yang dibentuk melalui hubungan dan pemahaman tentang komitmen peran kerja dengan penyedia layanan.

b. Role Script yaitu perilaku peran yang diharapkan, berlaku atau dikembangkan dalam pelayanan antarmuka dengan klien.

c. Role Congruence terjadi ketika pemahaman yang jelas tentang harapan peran ada dan terpenuhi.

d. Role Expansion, yaituperubahan peran dialami melalui tanggung jawab meningkat.

e. Role Discrepancy, yaitu kesenjangan yang terjadi di bawah pemenuhan antara aktual dan aspek direncanakan.

\section{ALAT ANALISA}

\section{Path Analysis}

Metode pengujian statistik yang akan digunakan pada model path analysis di penelitian ini adalah Partial Least Square. Partial Least Square (PLS) adalah bagian dari Structural Equation Modelling (SEM). Metode PLS ini merupakan metode baru yang sudah banyak dipakai dalam penenlitian karena dapat menggunakan jumlah sampel yang sedikit. Kelebihan dari PLS-SEM adalah metode ini mampu 
menyelesaikan berbagai model yang rumit/kompleks dengan berbagai variabel endogen dan variabel eksogen dengan banyaknya indikator yang ada, dapat dipakai pada sampel dengan jumlah kecil, dan dengan data distribusi yang ada (Abdillah \& Hartono, 2015).

\section{T-test}

Di dalam penelitian ini terdapat variabel intervening yaitu penghubung antara variabel dependen dan variabel independen. Pengujian hipotesis mediasi (variabel intervening) dapat dilakukan dengan prosedur T-test. Pengujian T-test digunakan untuk mendapatkan nilai t-statistik yang diperlukan apabila peneliti ingin melakukan uji hipotesis, sehingga peneliti dapat mengatakan pengaruh sebuah variabel dapat dikatakan memiliki pengaruh yang signifikan atau tidak. T-test dilakukan dengan menggunakan metode bootstrapping.

Metode bootstrapping adalah suatu proses pengujian re-sampling yang dilakukan oleh sistem komputer untuk mengukur akurasi pada sample estimate. Bootstraping digunakan untuk mengukur akurasi pada sample. Apabila nilai bootstrap lebih dari (>) 1.96 maka dinyatakan bahwa variabel tersebut memiliki pengaruh yang signifikan sedangkan apabila nilai bootstrap lebih rendah $(<)$ dari 1.96 , maka dinyatakan pengaruh variabel tersebut lemah (Abdillah \& Hartono, 2015).

\section{Statistik deskriptif}

Statistik deskriptif digunakan untuk menyajikan data secara deskriptif yang menggambarkan karakteristik responden serta jawaban-jawaban responden sehingga mampu digunakan sebagai kesimpulan dari hasil kuisioner yang sudah disebarkan selama penelitian ini.

\section{ANALISA DAN PEMBAHASAN}

\section{Analisa Deskriptif}

Tabel 1.Analisa Deskriptif Dimensi Transaction/Cost

\begin{tabular}{|l|c|c|c|c|c|c|c|}
\hline \multirow{2}{*}{ Indikator } & \multicolumn{5}{c|}{ Jawaban } & \multirow{2}{*}{ Mean } & $\begin{array}{c}\text { Std. } \\
\text { Dev. }\end{array}$ \\
\cline { 2 - 8 } & STS & TS & N & S & SS & & \\
\hline $\begin{array}{l}\text { Digital Marketing } \\
\text { mengurangi biaya promosi } \\
\text { konvensional (X1.1) }\end{array}$ & 0 & 7 & 33 & 65 & 15 & 3,73 & 0,750 \\
\hline $\begin{array}{l}\text { Digital Marketing } \\
\text { mempersingkat waktu } \\
\text { transaksi (X1.2) }\end{array}$ & 0 & 5 & 33 & 66 & 16 & 3,78 & 0,724 \\
\hline
\end{tabular}

Dimensi Transaction/cost mencerminkan kemampuan Digital Marketing pada perusahaan untuk menekan adanya biaya yang perlu dikeluarkan dalam teknik promosi perusahaan dengan tingkat efisiensi yang sangat tinggi karena digital marketing dapat menghemat biaya begitu besar. Pada tabel 1 dapat dijelaskan bahwa nilai mean terbesar dapat ditemui pada indikator X1.1 sebesar 3,78. Nilai ini menjelaskan bahwa mayoritas karyawan setuju terhadap pernyataan bahwa digital marketing mempersingkat waktu transaksi. Dengan adanya teknologi yang semakin maju maka penggunaan media digital dalam rangka proses transaksi semakin mudah. Hal seperti ini akan mempermudah dari sisi perusahaan dalam menjangkau target pasar yang lebih luas. Dengan adanya digital marketing yang hampir setiap masyarakat memiliki fasilitas tersebut, perusahaan tidak perlu menekan biaya promosi bagi perusahaanya. Dengan bantuan digital marketing, dengan sendirinya pelanggan akan mencari tahu sendiri. Secara tidak langsung hal ini akan berdampak pada efesiensi waktu yang akan dicapai oleh setiap pelanggan. Pelanggan tidak perlu datang dulu ke hotel untuk reservasi atau mencari segala sesuatu seperti fasilitas yang ditawarkan oleh hotel dan lain sebagainya, namun cukup bantuan digital marketing maka pelanggan dapat mempersingkat waktu dengan melakukan reservasi awal pada aplikasi yang mereka miliki. Dengan hal ini maka efisiensi karyawan pun semakin meningkat karena waktu transaksi semakin singkat pula.

Indikator X1.2 memiliki rata-rata sebesar 3,73 yang secara umum menunjukkan bahwa karyawan di hotel bintang empat merasakan bahwa dengan adanya digital marketing, maka biaya promosi secara konvensional berkurang secara drastis. Hal ini dikarenakan sistem digital marketing yang sangat merajalela dalam segala aspek pemasaran sehingga sistem konvensional perlahan ditinggalkan. Bila dahulu untuk melakukan promosi harus dengan media seperti baliho, banner, flyer, dan sebagainya, maka dengan adanya digital marketing media tersebut dapat digantikan dengan misalnya promosi lewat social media, e-mail, dan lewat aplikasi sehingga promosi yang dilakukan langsung tepat sasaran.

Tabel 2.Analisa Deskriptif Dimensi Incentive Program

\begin{tabular}{|l|c|c|c|c|c|c|c|}
\hline \multirow{2}{*}{ Indikator } & \multicolumn{5}{|c|}{ Jawaban } & \multirow{2}{*}{ Mean } & $\begin{array}{c}\text { Std. } \\
\text { Dev. }\end{array}$ \\
\cline { 2 - 7 } & STS & TS & N & S & SS & & \\
\hline $\begin{array}{l}\text { Digital } \\
\text { memberikan informasi yang } \\
\text { jelas (X1.3) }\end{array}$ & 0 & 6 & 30 & 65 & 19 & 3,81 & 0,756 \\
\hline $\begin{array}{l}\text { Digital Marketing } \\
\text { membantu karyawan } \\
\text { menjelaskan produk dan } \\
\text { layanan (X1.4) }\end{array}$ & 0 & 1 & 27 & 74 & 18 & 3,91 & 0,632 \\
\hline
\end{tabular}

Incentive Program menunjukkan pada Indikator X1.4 dapat dilihat memiliki mean sebesar 3,91 dan 
dapat disimpulkan bahwa bahwa digital marketing telah membantu karyawan menjelaskan produk dan layanan yang perusahaan miliki. Digital marketing membantu karyawan menjelaskan produk dan layanan, hal ini menandakan bahwa para karyawan setuju bahwa digital marketing membantu dalam memberikan informasi yang jelas, dalam artian, situs maupun akun jejaring sosial yang perusahaan gunakan membantu karyawan dalam menjelaskan informasi tentang produk-produk yang dimiliki oleh perusahaan, dengan begitu, kinerja karyawan bisa dialokasikan ke hal-hal lain yang lebih penting.

Indikator X1.3 juga memiliki nilai mean yang cukup tnggi, yaitu 3,82. Situs digital marketing maupun jejaring sosial yang dimiliki perusahaan, hal ini dapat dibuktikan dari website yang dimiliki oleh perusahaan, karyawan setuju dengan pernyataan bahwa media digital marketing yang perusahaan mereka miliki dapat memberikan informasi dengan jelas.

Tabel 3. Analisa Deskriptif Dimensi Site Design

\begin{tabular}{|c|c|c|c|c|c|c|c|}
\hline \multirow{2}{*}{ Indikator } & \multicolumn{5}{|c|}{ Jawaban } & \multirow{2}{*}{ Mean } & $\begin{array}{c}\text { Std. } \\
\text { Dev. }\end{array}$ \\
\cline { 2 - 7 } & STS & TS & N & S & SS & & \\
\hline $\begin{array}{l}\text { Desain Digital Marketing } \\
\text { menarik (X1.5) }\end{array}$ & 0 & 7 & 30 & 58 & 25 & 3,84 & 0,816 \\
\hline $\begin{array}{l}\text { Desain Digital Marketing } \\
\text { tersusun dengan rapi (X1.6) }\end{array}$ & 0 & 8 & 28 & 59 & 25 & 3,84 & 0,827 \\
\hline
\end{tabular}

Site Design merupakan tampilan menarik yang dapat menjadi senjata dalam memberikan nilai positif bagi para calon konsumen. Pada indikator X1.5 dan $\mathrm{X} 1.6$ menunjukan nilai mean yang sama yaitu sebesar 3,84 . Hal ini menandakan bahwa karyawan di industri hotel bintang 4 setuju bahwa antara design yang menarik dan design yang tersusun rapi sama pentingnya. Hal seperti ini harus diperhatikan bagi perusahaan demi memberikan nilai positif bagi pelanggan. Hal utama yang dibutuhkan konsumen dalam memanfatkan digital mareketing milik perusahaan adalah kemudahan dalam mengakses informasi yang mereka butuhkan. Apabila dari segi tampilan digital marketing menjawab kebutuhan tersebut, maka calon konsumen secara tidak langsung akan melanjutkan apa yang menjadi kebutuhan mereka. Menata tampilan demi tampilan supaya tersusun rapi, layout design yang menarik perhatian serta navigasi-navigasi yang jelas harus diperhatikan oleh perusahaan. Konsumen banyak memanfaatkan fasilitas digital marketing melalui handphone canggih mereka, oleh karena itu tampilan pada web komputer harus di sinkronkan dengan tampilan akses melalui smartphone para pelanggan.
Tabel 4. Analisa Deskriptif Dimensi Interactive

\begin{tabular}{|l|c|c|c|c|c|c|c|}
\hline \multirow{2}{*}{ Indikator } & \multicolumn{5}{|c|}{ Jawaban } & \multirow{2}{*}{ Mean } & $\begin{array}{c}\text { Std. } \\
\text { Dev. }\end{array}$ \\
\cline { 2 - 7 } & STS & TS & N & S & SS & & \\
\hline $\begin{array}{l}\text { Digital Marketing memudahkan } \\
\text { karyawan berkomunikasi } \\
\text { dengan konsumen (X1.7) }\end{array}$ & 0 & 11 & 32 & 56 & 21 & 3,73 & 0,856 \\
\hline $\begin{array}{l}\text { Digital Marketing membantu } \\
\text { karyawan dalam menanggapi } \\
\text { komplain (X1.8) }\end{array}$ & 0 & 10 & 25 & 65 & 20 & 3,79 & 0,815 \\
\hline
\end{tabular}

Interaksi dua arah antara perusahaan dengan konsumen merupakan hal terpenting yang tidak dapat ditinggalkan apalagi bila melalui digital marketing. Tabel 4 menunjukkan bahwa para karyawan setuju terhadap adanya dimensi Interactive dalam digital marketing. Terbukti dari indikator X1.8 dengan nilai mean sebesar 3,79 yang menyatakan bahwa digital marketing membantu karyawan dalam menanggapi komplain pelanggan. Hal pertama yang membuktikan bahwa digital marketing membantu karyawan dalam menanggapi komplain adalah pada saat konsumen memberikan masukan terhadap perusahaan akan lebih objektif menggunakan media dibandingkan secara tertulis. Selain itu, akan memudahkan bagi perusahaan dalam mengumpulkan data-data dibandingkan secara manual atau tertulis.

Pada indikator X1.7 juga menunjukkan bahwa digital marketing turut berperan dalam hal berkomunikasi diantara karyawan dan konsumen. Hal ini dilihat dari fasilitas yang perusahaan tawarkan didalam media seperti hotline 24 jam yang memberikan kemudahan bagi calon pelanggan untuk bertanya seputar kebutuhan mereka pada perusahaan tersebut.

Tabel 5. Analisa Deskriptif Dimensi Human Capital

\begin{tabular}{|l|c|c|c|c|c|c|c|}
\hline \multicolumn{1}{|c|}{ Indikator } & \multicolumn{5}{|c|}{ Jawaban } & \multirow{2}{*}{ Mean } & $\begin{array}{c}\text { Std. } \\
\text { Dev. }\end{array}$ \\
\cline { 2 - 8 } & STS & TS & N & S & SS & & \\
\hline $\begin{array}{l}\text { Digital Marketing memudahkan } \\
\text { karyawan dalam belajar produk } \\
\text { (Y1.1) }\end{array}$ & 0 & 5 & 26 & 69 & 20 & 3,87 & 0,730 \\
\hline $\begin{array}{l}\text { Digital Marketing memudahkan } \\
\text { karyawan dalam memberikan } \\
\text { layanan(Y1.2) }\end{array}$ & 0 & 4 & 30 & 60 & 26 & 3,90 & 0,768 \\
\hline
\end{tabular}

Human Capital mencerminkan suatu kemampuan pada perusahaan agar dapat menghasilkan solusi yang terbaik berdasarkan pengetahuan yang dimiliki oleh orang-orang yang berda di dalam pengetahuan tersebut. Dimensi ini dapat diukur dengan dua indikator yang terdapat pada Tabel 5. Indikator dengan jumlah rata-rata tanggapan tertinggi adalah Y1.2 sebesar 3,90. Karyawan hotel bintang empat di Jawa Timur mengakui bahwa digital marketing memudahkan karyawan dalam memberikan layanan terbaiknya untuk para konsumen. Dengan memanfaatkan digital marketing, maka karyawan akan semakin mudah dalam memberikan layanannya karena semua terintegrasi dalam suatu sistem online. 
Sebagai contoh, karyawan yang sedang melakukan promosi perusahaan kepada calon konsumen atau pelanggan, cukup memanfaatkan fasilitas digital marketing yang dimiliki perusahaan dalam memaparkan produknya (fasilitas hotel, gambar kamar hotel, serta tawaran lainnya yang dipaparkan melalui animasi maupun grafis).

Indikator Y1.1 memiliki jumlah rata-rata yang tidak jauh beda dengan indikator Y1.2 yaitu nilai mean sebesar 3,87. Karyawan hotel bintang empat setuju bahwa dengan adanya digital marketing, akan memudahkan mereka dalam mempelajari produk digital marketing yang dimiliki oleh perusahaan. Dalam hal ini, digital marketing berperan cukup besar dalam memandaikan para karyawannya. Selain karena teknologi yang semakin maju dan kebutuhan konsumen yang ingin serba cepat, maka mengakibatkan karyawan secara mau atau tidak mau harus menguasai media digital marketing tersebut. Dengan menguasai produk-produk yang dimiliki perusahaan, maka proses penyampaian informasi kepada pelanggan juga akan berjalan dengan baik. Maka dari itu peran digital marketing cukup berpengaruh terhadap pemahaman produk dari para karyawannya. Selain itu, media sosial dan aplikasi obrolan online sebagai sarana digital marketing juga dapat membantu para karyawan dalam pertukaran informasi sehingga produk-produk yang dimiliki oleh karyawan dapat dipelajari dengan lebih cepat dan mudah.

Tabel 6. Analisa Deskriptif Dimensi Structural Capital

\begin{tabular}{|l|c|c|c|c|c|c|c|}
\hline \multirow{2}{*}{ Indikator } & \multicolumn{5}{|c|}{ Jawaban } & \multirow{2}{*}{ Mean } & $\begin{array}{c}\text { Std. } \\
\text { Dev. }\end{array}$ \\
\cline { 2 - 8 } & STS & TS & N & S & SS & & \\
\hline $\begin{array}{l}\text { Digital Marketing } \\
\text { memudahkan karyawan } \\
\text { dalam mencari informasi } \\
\text { (Y1.3) }\end{array}$ & 0 & 5 & 22 & 71 & 22 & 3.92 & 0,726 \\
\hline $\begin{array}{l}\text { Digital Marketing } \\
\text { memudahkan karyawan } \\
\text { mempelajari SOP (Y1.4) }\end{array}$ & 0 & 4 & 38 & 56 & 22 & 3,80 & 0,770 \\
\hline
\end{tabular}

Structural capital pada hakekatnya ialah suatu kemampuan perusahaan dalam melakukan kegiatan rutinitas, serta struktur perusahaan yang mendukung usaha dari pekerja pada perusahaan tersebut untuk dapat menghasilkan kinerja intelektual yang optimal. Indikator Y1.3 memiliki nilai mean sebesar 3,92. Mayoritas karyawan setuju bahwa indikator ini merupakan yang terbesar dibandingkan indikator lannya dalam dimensi ini terbukti dengan $77,5 \%$ merasa setuju dan sangat setuju dengan pernyataan bahwa digital marketing memudahkan karyawan dalam mencari informasi. Baik itu informasi yang bersifat primer maupun sekunder. Sebagai contoh yaitu dengan adanya big data yang dimiliki perusahaan mengenai daftar pelanggannya sehingga memudah- kan karyawan dalam melakukan follow up kepada para konsumennya dan dapat diakses dari mana saja karena digital marketing ini berifat online dan terhubung antar jaringan. Perkembangan ini menyebabkan karyawan menjadi capable atau mampu dalam mengumpulkan informasi yang relevan yang dapat menjadi kontribusi berharga bagi perkembangan perusahaan.

Indikator Y1.4 juga menunjukkan angka yang cukup tinggi yaitu nilai mean 3,80 dengan total tanggapan 46,67\% menyatakan setuju dan $18,33 \%$ menyatakan sangat setuju. Hal ini menandakan mayoritas karyawan hotel bintang 4 setuju bahwa digital marketing memudahkan karyawan dalam mempelajari SOP atau Standar Operasional Prosedur. Proses implemenatsi SOP dibutuhkan perusahaan dalam rangka memperkenalkan SOP kepada setiap orang yang terlibat dalam struktur perusahaan tersebut dan menjadikan SOP menjadi bagian yang penting dalam setiap operasi rutin. Digital marketing sangat berperan di sini karena rekapan dokumen SOP yang didistribusikan sesuai dengan kebutuhan dapat diakses dengan mudah oleh seluruh anggota perusahaan, terutama yang terlibat langsung dalam SOP tersebut.

Tabel 7. Analisa Deskriptif Dimensi Customer Capital

\begin{tabular}{|l|c|c|c|c|c|c|c|}
\hline \multirow{2}{*}{ Indikator } & \multicolumn{5}{|c|}{ Jawaban } & \multirow{2}{*}{ Mean } & $\begin{array}{c}\text { Std. } \\
\text { Dev. }\end{array}$ \\
\cline { 2 - 7 } & STS & TS & N & S & SS & & \\
\hline $\begin{array}{l}\text { Digital Marketing } \\
\text { memampukan karyawan } \\
\text { dekat dengan pelanggan } \\
(Y 1.5)\end{array}$ & 0 & 8 & 26 & 56 & 30 & 3,90 & 0,850 \\
\hline $\begin{array}{l}\text { Digital Marketing } \\
\text { memudahkan karyawan } \\
\text { berkomunikasi dengan } \\
\text { stakeholder (Y1.6) }\end{array}$ & 0 & 7 & 31 & 57 & 25 & 3,83 & 0,820 \\
\hline
\end{tabular}

Customer Capital atau juga dikenal sebagai relational capital atau external capital terdiri dari hubungan dengan pelanggan dan pemasok, pemerintah atau asosiasi industri terkait, nama merek, merek dagang dan reputasi. Customer capital merupakan hubungan yang harmonis yang dimiliki oleh perusahaan kepada para mitra kerja maupun kepada para pelanggannya. Indikator Y1.5 dengan nilai ratarata 3,90 menunjukkan karyawan setuju bahwa digital marketing mampu membuat karyawan lebih dekat dengan pelanggan. Sebagai contoh yaitu pada saat karyawan melakukan proses follow-up melalui $e$ mailmaupun SMS untuk dapat berkomunikasi secara personal mengenai informasi tentang informasiinformasi maupun promosi terbaru. Pelanggan juga dapat melakukan kontak kepada perusahaan melalui saranasocial media, telepon, e-mail dan situs resmi dari pihak hotel. Hal ini tentu saja membuat karyawan 
memiliki rasa kedekatan yang baik dengan pelanggan dan dapat meningkatkan performa dari perusahaan karena hal tersebut.

Indikator Y1.6 memperkuat indikator Y1.5 diatas dengan nilai mean sebesar 3,83. Kemitraan dengan stakeholder merupakan hal yang sangat diperhatikan oleh perusahaan karena stakeholder menjadi salah satu aset penting yang harus dijaga. Dengan adanya hubungan yang baik dengan stakeholder, maka akan berhubungan langsung dengan performa perusahaan. Dalam hal ini pelanggan adalah salah satu bagian dari stakeholder yang harus dijaga baik hubungannya dengan perusahaa.Maka kemudahan dalam berkomunikasi dengan stakeholder berarti secara langsung pihak penyedia layanan hotel telah mendekatkan diri dengan pelanggan. Dalam hal ini pihak karyawan setuju bahwa Digital Marketing memudahkan karyawan berkomunikasi dengan stakeholder.

Tabel 8. Analisa Deskriptif Dimensi Features

\begin{tabular}{|l|c|c|c|c|c|c|c|}
\hline \multirow{2}{*}{ Indikator } & \multicolumn{5}{|c|}{ Jawaban } & \multirow{2}{*}{ Mean } & $\begin{array}{c}\text { Std. } \\
\text { Dev. }\end{array}$ \\
\cline { 2 - 7 } & STS & TS & N & S & SS & & 0,730 \\
\hline $\begin{array}{l}\text { Digital Marketing memiliki } \\
\text { teknologi up to date (Y2.1) }\end{array}$ & 0 & 3 & 32 & 63 & 22 & 3,87 & 0,730 \\
\hline $\begin{array}{l}\text { Digital Marketing memiliki } \\
\text { database pelanggan (Y2.2) }\end{array}$ & 0 & 5 & 32 & 68 & 15 & 3,78 & 0,713 \\
\hline
\end{tabular}

Features dalam digital marketing merupakan fitur-fitur ekstra atau tambahan yang ada untuk melengkapi fitur utama dari digital marketing. Features ini bersifat pelengkap karena berhubungan dengan aspek tambahan yang dapat saling melengkapi. Indikator terkuat yang mempengaruhi dimensi ini adalah indikator Y2.1 dengan nilai mean sebesar 3,87. Indikator ini membahas tentang fitur-fitur dalam digital marketing yang memiliki teknologi yang up to date. Artinya para karyawan setuju dengan adanya digital marketing yang memiliki teknologi terbaru sesuai dengan perkembangan jaman yang akan menunjang persepsi pelanggan yang dapat berdampak langsung terhadap kinerja karyawan, yaitu mempermudah karyawan dengan cara mengedukasi dan menarik minat pelanggan. Dengan menguasai dan memanfaatkan teknologi yang semakin berkembang, maka karyawan akan dapat lebih efektif untuk menjangkau para konsumennya yang juga memanfaatkan digital marketing untuk pencarian informasi.

Dengan memiliki dan menggunakan teknologi yang up to date, maka database pelanggan yang sudah diisi sebelumnya oleh pelanggan akan dapat tersimpan dengan rapi melalui media digital marketing dan akan berdampak kepada perusahaan karena aset perusahaan ini terjaga dengan baik. Database pelanggan akan meningkatkan nilai-nilai yang dimiliki perusahaan secara otomatis, data-data ini pun dapat dijual nantinya dan akan masuk sebagai Big Data. Hal ini disetujui oleh responden pada indikator Y2.2 dengan responden setuju sebanyak 56,67\% dan menjawab sangat setuju sebesar $12,5 \%$.

Tabel 9. Analisa Deskriptif Dimensi Reliability

\begin{tabular}{|c|c|c|c|c|c|c|c|}
\hline \multirow{2}{*}{ Indikator } & \multicolumn{5}{|c|}{ Jawaban } & \multirow{2}{*}{ Mean } & \multirow{2}{*}{$\begin{array}{l}\text { Std. } \\
\text { Dev. }\end{array}$} \\
\hline & STS & TS & $\mathbf{N}$ & $\mathbf{S}$ & SS & & \\
\hline $\begin{array}{l}\text { Digital Marketing mampu } \\
\text { membantu karyawan } \\
\text { memberikan informasi }(\mathrm{Y} 2.3)\end{array}$ & 0 & 6 & 31 & 67 & 16 & 3,78 & 0,736 \\
\hline $\begin{array}{lr}\text { Digital } & \text { Marketing } \\
\text { memudahkan } & \text { karyawan } \\
\text { berkomunikasi } & \text { dengan } \\
\text { pelanggan }(Y 2.4) & \end{array}$ & 0 & 5 & 42 & 48 & 25 & 3,78 & 0,821 \\
\hline
\end{tabular}

Reliability merupakan kemungkinan digital marketing dalam menjalankan fungsinya dengan baik setiap kali digunakan. Pada indikator Y2.3 dan Y2.4 dapat kita lihat memiliki mean yang sama yaitu sebesar 3,78. Hal ini menandakan para karyawan merasakan bahwa digital marketing mampu membantu karyawan dalam memberikan informasi maupun memudahkan karyawan berkomunikasi dengan pelanggan dengan sama baiknya. Dengan memanfaatkan digital marketing, dapat secara langsung memberikan informasi tanpa perlu kita jelaskan. Pelanggan dapat secara langsung melihat informasi yang terdapat di website maupun akun sosial perusahaan. Komunikasi juga merupakan hal yang perlu diperhatikan. Komunikasi yang terjadi adalah 2 arah dan tidak ada halangan maupun hambatan yang terjadi, komunikasi tersebut terjadi secara real-time dan tidak ada tunggu menunggu untuk menyampaikan pesan sehingga informasi yang diberikan akan secara langsung tersampaikan kepada pelanggan melalui aplikasi digital marketing yang memudahkan karyawan berkomunikasi dengan pelanggan

Tabel 10. Analisa Deskriptif Dimensi Conformance

\begin{tabular}{|l|c|c|c|c|c|c|c|}
\hline \multirow{2}{*}{ Indikator } & \multicolumn{5}{|c|}{ Jawaban } & \multirow{2}{*}{ Mean } & $\begin{array}{c}\text { Std. } \\
\text { Dev. }\end{array}$ \\
\cline { 2 - 7 } & STS & TS & N & S & SS & & \\
\hline $\begin{array}{l}\text { Digital Marketing mampu } \\
\text { memberikan keamanan bagi } \\
\text { pelanggan (Y2.5) }\end{array}$ & 0 & 7 & 28 & 69 & 16 & 3,78 & 0,744 \\
\hline $\begin{array}{l}\text { Digital Marketing membantu } \\
\text { karyawan dalam meyakinkan } \\
\text { pelanggan (Y2.6) }\end{array}$ & 0 & 3 & 33 & 72 & 12 & 3,78 & 0,651 \\
\hline
\end{tabular}

Conformance merupakan kesesuaian yang terjadi antara karyawan dan pelanggan, baik dalam hal kemanan maupun kepercayaan. Pada 2 indikator dalam dimensi ini, yaitu indikator Y2.5 dan Y2.6 dapat kita temui bahwa kedua indikator ini memiliki mean yang sama pula yaitu sebesar 3,78. Digital 
marketing mampu memberikan keamanan bagi pelanggan, yaitu dengan cara merahasiakan data-data pribadi milik pelanggan yang telah mereka isi sebelumnya. Sistem ini membuat pelanggan merasa nyaman dan aman karena tidak khawatir data pribadi mereka dapat diretas oleh pihak-pihak yang tidak bertanggungjawab.

Diikuti juga dengan Indikator Y2.6 dimana 70\% dari para responden menjawab setuju dengan pernyataan ini, digital marketing dapat membantu karyawan dalam meyakinkan pelanggan, dengan web design yang menarik, situs berisi informasi yang berbobot, dan adanya review dari pelanggan-pelanggan sebelumnya, tentu pelanggan akan semakin tertarik melihat dan mencari tau tentang perusahaan maupun produk yang kita sedang pasarkan. Hal ini menyebabkan performa organisasi yang meningkat karena pelanggan merasa yakin akan perusahaan.

Tabel 11. Analisa Deskriptif Dimensi Durability

\begin{tabular}{|c|c|c|c|c|c|c|c|}
\hline \multirow{2}{*}{ Indikator } & \multicolumn{5}{|c|}{ Jawaban } & \multirow{2}{*}{ Mean } & $\begin{array}{c}\text { Std. } \\
\text { Dev. }\end{array}$ \\
\cline { 2 - 8 } & STS & TS & N & S & SS & & 0,673 \\
\hline $\begin{array}{l}\text { Digital Marketing aman dari } \\
\text { hacker (Y2.7) }\end{array}$ & 0 & 2 & 29 & 70 & 19 & 3,88 & 0,673 \\
\hline $\begin{array}{l}\text { Digital Marketing memiliki } \\
\text { konsistensi yang baik (Y2.8) }\end{array}$ & 0 & 4 & 32 & 67 & 17 & 3,81 & 0,711 \\
\hline
\end{tabular}

Durability adalah ketahanan dari digital marketing itu sendiri, apakah digital marketing tersebut aman dari gangguan para peretas yang tidak bertanggungjawab, dan juga ketahanan yang dilihat dari jangka waktu digital marketing ini sendiri dapat dimanfaatkan dengan baik oleh perusahaan. Dalam hal ini, dengan nilai mean sebesar 3,88, mayoritas para karyawan setuju dengan adanya programmer yang handal akan membuat akun-akun digital marketing dari perusahaan akan aman dari hacker dan tidak akan bocor segala data dan konten yang ada didalamnya, yang semua terjaga demi privasi dan data pribadi perusahaan. Indikator Y2.7 ini menunjukan bahwa digital marketing yang digunakan oleh perusahaan sudah aman dari gangguan hacker maupun gangguan lainnya.

Indikator Y2.8 yang memiliki mean sebesar 3,81 ini juga mengindikasikan bahwa karyawan setuju dengan digital marketing yang mereka miliki, bahwa digital marketing yang mereka miliki memiliki konsistensi yang baik. Yang dimaksudkan dengan konsistensi yang baik adalah situs yang tidak mudah down, akun-akun jejaring sosial yang selalu aktif, maupun akun email dan hotline yang selalu aktif dalam menerima berbagai informasi dan keluhan pelanggan maupun menerima kritik dan saran.

Kedua indikator ini, yaitu Y2.7 dan Y2.8 merupakan dua indikator yang saling berkaitan satu sama lain, karena apabila akun tersebut sudah terkena hack, maka kepercayaan yang sudah dibangun oleh perusahaan akan hilang dan reputasi perusahaan pun akan menurun karena ketidakpercayaan para pelangan terhadap perusahaan dan menganggap bahwa perusahaan kurang konsisten dalam mengelola digital marketing yang dimiliki.

Tabel 12. Analisa Deskriptif Dimensi Serviceability

\begin{tabular}{|c|c|c|c|c|c|c|c|}
\hline \multirow{2}{*}{ Indikator } & \multicolumn{5}{|c|}{ Jawaban } & \multirow{2}{*}{ Mean } & $\begin{array}{c}\text { Std. } \\
\text { Dev. }\end{array}$ \\
\cline { 2 - 7 } & STS & TS & N & S & SS & & \\
\hline $\begin{array}{l}\text { Digital Marketing mampu } \\
\text { memberikan pelayanan } \\
\text { terbaik(Y2.9) }\end{array}$ & 0 & 6 & 28 & 64 & 22 & 3,85 & 0,771 \\
\hline $\begin{array}{l}\text { Digital Marketing mampu } \\
\text { menanggapi komplain } \\
\text { pelanggan (Y2.10) }\end{array}$ & 0 & 5 & 27 & 76 & 12 & 3,79 & 0,670 \\
\hline
\end{tabular}

Serviceability adalah kemudahan layanan dari perusahaan maupun adanya perbaikan ketika sedang dibutuhkan oleh pelanggan. Hal ini tentu saja harus diperhatikan dalam memaksimalkan peran digital marketing sebagai strategi promosi yang diberikan oleh perusahaan.

Pada indikator Y2.9, digital marketing mampu memberikan pelayanan terbaik. Hal ini artinya bahwa bantuan digital marketing perusahaan sudah mampu memberikan layanan yang terbaik. Artinya pelanggan bisa mendapatkan informasi dengan mudah, tidak kesulitan dalam menggali informasi, maupun tidak menyulitkan pelanggan dalam mengakses digital marketing milik perusahaan. Karyawan setuju bahwa digital marketing yang mereka gunakan mampu memberikan pelayanan terbaik, sebab dengan hal itu, pelanggan dapat dengan mudah mencari informasi tanpa karyawan harus memberikan penjelasanpenjelasan umum. Dalam hal ini karyawan sangat terbantu dengan adanya digital marketing. Nilai mean sebesar 3,85 menjadi bukti bahwa karyawan merasa terbantu dengan adanya digital marketing.

Digital marketing mampu menanggapi komplain pelanggan, dalam situs yang dimiliki oleh perusahaan tentu akan terdapat kolom komentar, kritik, dan saran di dalamnya. Hal ini sudah dirasakan karyawan dan hal tersebut membuat mereka mengerti tentang apa saja yang perlu diperhatikan secara ekstra dan mengerti keluhan-keluhan apa yang dirasakan oleh pelanggan, dan dapat ditanggapi dengan cepat oleh pihak perusahaan sehingga citra perusahaan tidak buruk. Indikator Y2.10 ini memiliki nilai Mean 3,79 , nilai yang cukup tinggi dan dapat dikatakan bahwa para karyawan hotel bintang 4 yang menjadi responden dalam penelitian ini setuju dengan pernyataan bahwa digital marketing yang mereka gunakan mampu mengatasai komplain dari para pelanggan. 
Tabel 13. Analisa Deskriptif Dimensi Aesthetics

\begin{tabular}{|c|c|c|c|c|c|c|c|}
\hline \multirow{2}{*}{ Indikator } & \multicolumn{5}{|c|}{ Jawaban } & \multirow{2}{*}{ Mean } & $\begin{array}{c}\text { Std. } \\
\text { Dev. }\end{array}$ \\
\cline { 2 - 7 } & STS & TS & N & S & SS & & 0,769 \\
\hline $\begin{array}{l}\text { Digital Marketing memiliki } \\
\text { tampilan yang menarik (Y2.11) }\end{array}$ & 0 & 6 & 34 & 61 & 19 & 3,78 & 0,0 \\
\hline $\begin{array}{l}\text { Digital Marketing memiliki } \\
\text { tampilan yang modern(Y2.12) }\end{array}$ & 0 & 3 & 34 & 67 & 16 & 3,80 & 0,690 \\
\hline
\end{tabular}

Aesthetic merupakan estetika atau keindahan yang menyangkut komposisi, konstruksi dan penataan daripada situs digital marketing itu sendiri. Indikator Y2.11 memiliki nilai Mean 3,78. Nilai ini menandakan bahwa karyawan setuju dengan pernyataan bahwa digital marketing yang mereka buat memiliki tampilan yang menarik, hal ini sangat berpengaruh dan berdampak kepada pelanggan. Tampilan dan desain dari suatu situs digital marketing yang menarik akan membuat pelanggan merasa betah dan tertarik untuk melakukan pencarian informasi lebih dalam lagi mengenai perusahaan. Oleh dari itu, tampilan digital marketing harus dibuat semenarik mungkin supaya pelanggan tidak merasa jenuh dan bosan.

Indikator Y2.12 juga disetujui oleh sebagian besar karyawan. Dengan nilai mean 3,80 dapat disimpulkan bahwa karyawan juga memiliki digital marketing dengan tampilan yang modern, hal ini juga mempengaruhi rasa ketertarikan pelanggan untuk berlama-lama di situs digital marketing. Selain konten dan isi yang menarik, desain yang futuristik dan moderen akan menarik perhatian para pelanggan. Estetika merupakan hal penting yang wajib diperhatikan dalam sebuah situs maupun digital marketing lainnya. Tanpa estetika yang baik, tentu desain dan tampilan situs tersebut menjadi tanpa adanya tujuan dan tidak enak dilihat serta sulit dipahami. Dengan adanya estetika yang baik dan menarik, maka rasa ingin tahu dari konsumen juga akan semakin tinggi.

Tabel 14. Analisa Deskriptif Dimensi Role Set

\begin{tabular}{|c|c|c|c|c|c|c|c|}
\hline \multirow{2}{*}{ Indikator } & \multicolumn{5}{|c|}{ Jawaban } & \multirow{2}{*}{ Mean } & \multirow{2}{*}{$\begin{array}{l}\text { Std. } \\
\text { Dev. }\end{array}$} \\
\hline & STS & TS & $\mathbf{N}$ & $\mathbf{S}$ & SS & & \\
\hline $\begin{array}{l}\text { Digital Marketing membantu } \\
\text { membangun hubungan kerjasama } \\
\text { team }(\mathrm{Z} 1.1)\end{array}$ & 0 & 3 & 26 & 73 & 18 & 3,88 & 0,673 \\
\hline $\begin{array}{l}\text { Digital Marketing memudahkan } \\
\text { karyawan dalam melayani } \\
\text { konsumen }(\mathrm{Z} 1.2)\end{array}$ & 0 & 4 & 32 & 72 & 12 & 3,77 & 0,667 \\
\hline
\end{tabular}

Role set merupakan peran set internal yang dibentuk melalui hubungan dan pemahaman tentang komitmen peran kerja dengan penyedia layanan. Digital Marketing membantu hubungan kerjasama team, dikarenakan komunikasi yang mudah, intens, dan berisi. Media digital marketing membantu dalam hal ini, karyawan dapat mengirimkan pesan dan dibaca pada saat itu juga, sehingga pertukaran informasi yang terjadi otomatis meningkat dalam segi kecepatan, efisiensi akan tercipta dan kerjasama team yang bagus akan terjadi seiring dengan pertukaran informasi yang cepat. Dapat kita lihat Indikator Z1.1 dengan nilai mean 3,88 menunjukkan bahwa karyawan setuju dengan hal tersebut.

Indikator Z1.2 memiliki nilai mean 3,77, dapat dikatakan bahwa digital marketing memudahkan karyawan dalam melayani konsumen, dengan adanya digital marketing, karyawan dapat menanggapi konsumen secara cepat dan tepat. Dengan bantuan media digital marketing, frekuensi karyawan untuk berbicara dengan pelanggan akan berkurang karena semua dapat diakses secara online.

Tabel 15. Analisa Deskriptif Dimensi Role Script

\begin{tabular}{|c|c|c|c|c|c|c|c|}
\hline \multirow{2}{*}{ Indikator } & \multicolumn{5}{|c|}{ Jawaban } & \multirow{2}{*}{ Mean } & $\begin{array}{c}\text { Std. } \\
\text { Dev. }\end{array}$ \\
\cline { 2 - 7 } & STS & TS & N & S & SS & & \\
\hline $\begin{array}{l}\text { Digital Marketing meningkatkan } \\
\text { kualitas layanan hotel (Z1.3) }\end{array}$ & 0 & 4 & 28 & 68 & 20 & 3,87 & 0,718 \\
\hline $\begin{array}{l}\text { Digital Marketing memudahkan } \\
\text { hotel memberikan layanan yang } \\
\text { berkesinambungan (Z1.4) }\end{array}$ & 0 & 7 & 28 & 74 & 11 & 3,74 & 0,701 \\
\hline
\end{tabular}

Role script merupakanperilaku peran yang diharapkan, berlaku atau dikembangkan dalam pelayanan antarmuka dengan klien. Indikator Z1.3 memiliki nilai mean yang cukup tinggi, yaitu 3,87, dalam hal ini dapat diindikasikan bahwa karyawan setuju dengan pernyataan tersebut, yaitu digital marketing meningkatkan kualitas layanan hotel. Dengan adanya digital marketing karyawan merasa terbantu dalam meningkatkan kualitas layanan hotel, karena dalam media yang dimiliki oleh perusahaan, pelanggan dapat secara langsung melihat, memesan, maupun membayar layanan yang mereka inginkan.

Digital marketing memudahkan hotel memberikan layanan yang berkesinambungan. Indikator Z1.4 memiliki nilai mean yaitu 3,74 yang berarti benar adanya bahwa karyawan merasa bahwa digital marketing membantu mereka dan memudahkan hotel dalam memberikan layanan terbaiknya. Hal ini disebabkan karena pelanggan dapat secara langsung memesan semua yang layanan yang ada dan saling berkesinmbungan antara satu sama lain.

Role Congruence terjadi ketika pemahaman yang jelas tentang harapan peran ada dan terpenuhi. Indikator Z1.5 memiliki nilai mean 3,81, yaitu menyatakan bahwa digital marketing membantu hotel dalam menarik pelanggan, hal ini disebabkan karena digital marketing meningkatkan keinginan pelanggan dengan desain situs yang menarik, dan juga didukung dengan situs yang tidak rumit serta mudah untuk 
diakses. Apabila situs dan media digital marketing yang dituju sulit untuk diakses, kecenderungan pelanggan akan berganti dan akan berpindah ke website atau situs yang lain. Dalam hal ini $81,67 \%$ karyawan setuju dengan pernyataan diatas.

Tabel 16. Analisa Deskriptif Dimensi Role Congruence

\begin{tabular}{|l|c|c|c|c|c|c|c|}
\hline \multirow{2}{*}{ Indikator } & \multicolumn{5}{|c|}{ Jawaban } & \multirow{2}{*}{ Mean } & $\begin{array}{c}\text { Std. } \\
\text { Dev. }\end{array}$ \\
\cline { 2 - 7 } & STS & TS & N & S & SS & & \\
\hline $\begin{array}{l}\text { Digital Marketing membantu } \\
\text { hotel dalam menarik } \\
\text { pelanggan (Z1.5) }\end{array}$ & 0 & 7 & 20 & 82 & 11 & 3,81 & 0,674 \\
\hline $\begin{array}{l}\text { Digital Marketing membantu } \\
\text { hotel dalam memberikan } \\
\text { informasi (Z1.6) }\end{array}$ & 0 & 3 & 28 & 69 & 20 & 3,88 & 0,697 \\
\hline
\end{tabular}

Pernyataan diatas dapat kita artikan bahwa digital marketing mampu membantu karyawan dalam memberikan informasi maupun menyampaikannya. Indikator Z1.6 dengan nilai mean 3.89 dapat disimpulkan bahwa para karyawan setuju dengan pernyataan tersebut, karena digital marketing dapat secara langsung memberikan informasi tanpa perlu kita jelaskan. Pelanggan dapat secara langsung melihat informasi yang terdapat di media digital marketing milik perusahaan.

Tabel 17. Analisa Deskriptif Dimensi Role Expansion

\begin{tabular}{|l|c|c|c|c|c|c|c|}
\hline \multirow{2}{*}{ Indikator } & \multicolumn{5}{|c|}{ Jawaban } & \multirow{2}{*}{ Mean } & $\begin{array}{c}\text { Std. } \\
\text { Dev. }\end{array}$ \\
\cline { 2 - 7 } & STS & TS & N & S & SS & & \\
\hline $\begin{array}{l}\text { Digital Marketing membantu } \\
\text { hotel dalam memperoleh } \\
\text { pelanggan baru (Z1.7) }\end{array}$ & 0 & 3 & 24 & 79 & 14 & 3,87 & 0,632 \\
\hline $\begin{array}{l}\text { Digital Marketing membantu } \\
\text { karyawan dalam banyak tugas } \\
\text { (multi task) (Z1.8) }\end{array}$ & 0 & 7 & 20 & 79 & 14 & 3,83 & 0,699 \\
\hline
\end{tabular}

Role Expansion yaituperubahan peran dialami melalui tanggung jawab meningkat. Pada indikator Z1.7 dapat dilihat bahwa digital marketing membantu hotel dalam memperoleh pelanggan baru. Dengan nilai mean 3,88, dapat kita artikan bahwa karyawan setuju dengan digital marketing yang membantu memperoleh pelanggan baru, hal ini bisa dijelaskan dalam pembuatan media digital marketing yang menarik dan modern akan menarik perhatian pelanggan dan meningkatkan keinginan pelanggan untuk mengetahui lebih dalam mengenai konten di dalamnya. Dari hal tersebut dapat diartikan bahwa dengan memberikan digital marketing dapat membantu karyawan dalam memperoleh pelanggan.

Indikator Z1.8 yang menyatakan digital marketing membantu karyawan dalam banyak tugas (multi task) memiliki nilai mean yang berbeda tidak terlalu jauh yaitu sebesar 3,86. Artinya karyawan tentu setuju dengan pernyataan tersebut, digital marketing sangat membantu, aplikasi dan media yang disediakan membantu karyawan dalam mengerjakan beberapa tugas sekaligus, untuk mempersingkat waktu kerja. Dengan dapat melakukan multitask, maka pekerjaan akan semakin efektif dan efisien dan berpengatuh kepada meningkatknya performa organisasi.

Tabel 18. Analisa Deskriptif Dimensi Role Discrepancy

\begin{tabular}{|l|c|c|c|c|c|c|c|}
\hline \multirow{2}{*}{ Indikator } & \multicolumn{5}{|c|}{ Jawaban } & \multirow{2}{*}{ Mean } & $\begin{array}{c}\text { Std. } \\
\text { Dev. }\end{array}$ \\
\cline { 2 - 7 } & STS & TS & N & S & SS & & \\
\hline $\begin{array}{l}\text { Digital Marketing membantu } \\
\text { karyawan dalam } \\
\text { berimprovisasi (Z1.9) }\end{array}$ & 0 & 5 & 29 & 69 & 17 & 3,82 & 0,719 \\
\hline $\begin{array}{l}\text { Digital Marketing } \\
\text { meningkatkan kreativitas } \\
\text { karyawan (Z1.10) }\end{array}$ & 0 & 4 & 22 & 79 & 15 & 3,88 & 0,653 \\
\hline
\end{tabular}

Discrepancy merupakan kesenjangan yang terjadi di bawah pemenuhan antara aktual dan aspek direncanakan. Pada dimensi ini dapat kita lihat indikator Z1.10 memiliki mean sebesar 3,88 yang berarti para karyawan setuju bahwa digital marketing meningkatkan kreativitas karyawan. Dengan adanya media berupa digital marketing ini, mau tidak mau karyawan harus mampu berpikir secara kreatif dan inovatif supaya unggul dari pesaing dan para konsumen semakin tertarik dengan keberadaan dan kemampuan perusahaan.

Sedangkan pada indikator Z1.9 juga memiliki mean yang cukup tinggi sebesar Z1.9. Digital marketing digunakan para karyawan dalam berimprovisasi dalam rangka supaya menjadi pembeda diantara yang lainnya dan nantinya akan meningkatkan performa perusahaan.

\section{Evaluasi Path Coefficient dan Coefficient of Determination}

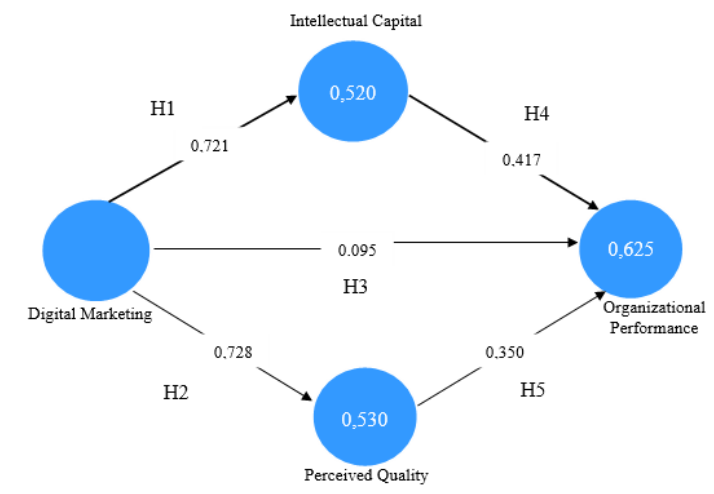

Gambar 2. Path Coefficient dan Coefficient of determination

Pada analisa path coefficient ini telah dibuktikan bahwa Intellectual Capital dan Perceived Quality merupakan variabel intervening dimana memperkuat hubungan antara Digital Marketing dan Organizational Performance. Dari gambar diatas dapat dijelaskan bahwa nilai path coefficient terbesar ditun- 
jukkan dari pengaruh Digital Marketing terhadap Perceived Quality sebesar 0,728. Sedangkan kontribusi nilai Digital Marketing terhadap Intellectual Capital tidak berbeda jauh, sebesar 0,721. Hubungan menuju Organizational Performance terkuat juga didapat ketika Digital Marketing melewati Intellectual Capital dan Perceived Quality menuju Organizational Performance.

Pada hubungan Digital Marketing terhadap Organizational Performance secara langsung memiliki path coefficient senilai 0,095. Lalu ketika hubungan tersebut melalui variabel Intellectual Capital terlebih dahulu, maka nilai dari path coefficient meningkat menjadi $0,301(=0,721 \times 0,417)$. Sehingga hal ini merupakan bukti bahwa Intellectual Capital merupakan variabel intervening yang memperkuat hubungan antara Digital Marketing dengan Organizational Performance.

Selain Intellectual Capital, Perceived Quality juga memiliki peranan sebagai variabel intervening dimana memperkuat hubungan antara Digital Marketing dengan Organizational Performance. Diketahui bahwa nilai path coefficient dari hubungan Digital Marketing dengan Organizational Performance sebesar 0,095. Lalu ketika hubungan tersebut melalui variabel Perceived Quality maka nilaitersebut meningkat menjadi $0,255(=0,728 \times 0,350)$. Sehingga dari hal tersebut menjadi bukti bahwa Perceived Quality sebagai variabel intervening memperkuat hubungan yang sudah ada.

Jadi kesimpulan bagi seluruh variabel dalam model ini memiliki path coefficient dengan angka yang positif. Artinya, jika semakin besar nilai path coefficient pada satu variabel independen terhadap variabel dependen, maka semakin kuat juga pengaruh antara variabel independen terhadap variabel dependen tersebut. Namun hubungan Digital Marketing terhadap Organizational Performance secara langsung memiliki angka yang paling rendah, yaitu 0,095 yang berarti pengaruh Digital Marketing terhadap Organizational Performance rendah.

Hubungan Digital Marketing terhadap Organizational Performance secara langsung tidak kuat karena hanya dengan media digital, industri hotel bintang 4 di Jawa Timur belum mampu meningkatkan performa organisasinya. Memiliki digital marketing yang baik namun tidak diikuti dengan kemampuan sumber daya berupa modal intelektual para karyawan yang mau terus belajar dan mengikuti perkembangan zaman, dan juga kurangnya persepsi kualitas yang baik dari mata masyarakat maka perusahaan tidak mampu meningkatkan Organizational Performance. Pada objek penelitian ini sangat dibutuhkan peran Intellectual Capital dan Perceived Quality menuju Organizational Performance.

Sementara itu, nilai coefficient of determination $\left(\mathrm{R}^{2}\right)$ yang pada gambar ditunjukkan pada angka di dalam lingkaran variabel Intellectual Capital, Perceived Quality, dan Organizational Performance, membuktikan bahwa variabel Intellectual Capital dipengaruhi oleh Digital Marketing dengan nilai varian sebesar 0,520. Artinya, sebanyak $48 \%$ lainnya dipengaruhi oleh variabel lain diluar penelitian. Lalu variabel Perceived Quality dipengaruhi oleh Digital Marketing dengan nilai varian sebesar 0,530. Artinya pengaruh Digital Marketing terhadap Perceived Quality sebesar 53\%, sedangkan 47\% lainnya dijelaskan oleh variabel lain diluar penelitian. Sedangkan variabel Organizational Performance dipengaruhi oleh variabel Digital Marketing, Intellectual Capital, dan Perceived Quality dengan nilai varian 0,625. Maka dari itu diketahui bahwa didalam penelitian ini Organizational Performance dipengaruhi sebesar 62,5\% dimana 37,5\% terbentuknya Organizational Performance dijelaskan oleh variabel-variabel lain diluar penelitian.

\section{T-Statistic}

Tabel 19. T-Statistic

\begin{tabular}{|c|c|c|c|c|}
\hline & $\begin{array}{c}\text { Original } \\
\text { Sample (O) }\end{array}$ & $\begin{array}{c}\text { Sample Mean } \\
\text { (M) }\end{array}$ & $\begin{array}{c}\text { Standard } \\
\text { Error } \\
\text { (STERR) }\end{array}$ & $\begin{array}{c}\text { T Statistics } \\
(\text { (O/STERR) }\end{array}$ \\
\hline $\begin{array}{c}\text { Digital Marketing -> } \\
\text { Intellectual Capital }\end{array}$ & 0,721 & 0,725 & 0,044 & 16,403 \\
\hline $\begin{array}{c}\text { Digital Marketing -> } \\
\text { Perceived Quality }\end{array}$ & 0,728 & 0,734 & 0,047 & 15,531 \\
\hline $\begin{array}{c}\text { Digital Marketing -> } \\
\text { Organizational } \\
\text { Performance }\end{array}$ & 0,095 & 0,084 & 0,105 & 0,903 \\
\hline $\begin{array}{c}\text { Intellectual Capital -> } \\
\text { Organizational } \\
\text { Performance }\end{array}$ & 0,417 & 0,417 & 0,083 & 5,011 \\
\hline $\begin{array}{c}\text { Perceived Quality -> } \\
\text { Organizational } \\
\text { Performance }\end{array}$ & 0,350 & 0,361 & 0,111 & 3,163 \\
\hline
\end{tabular}

Dengan melihat table 19, dapat diartikan bahwa nilai original sample $(\mathrm{O})$ adalah nilai path coefficient yang menunjukkan kekuatan pengaruh dari satu latent variable ke satu latent variable lainnya. Sedangkan nilai pada kolom sample mean (M) menunjukkan nilai tengah dari path coefficient. Sedangkan standard error (STDERR), menunjukkan nilai error pada sampel mean. Nilai $T$ statistics untuk melihat nilai $\mathrm{T}$ hitung yang akan digunakan untuk pengujian hipotesis, dimana $T$ statistics yang memiliki nilai di atas 1,96 memiliki pengaruh.

\section{PEMBAHASAN}

\section{Digital Marketing terhadap Intellectual Capital}

Hasil penelitian ini menunjukkan bahwa variabel Digital Marketing dari hotel bintang 4 di Jawa Timur memiliki pengaruh yang positif terhadap Marketing Capability dengan hasil nilai uji $T$ statistics $>1,96$ yaitu sebesar16,403. 
Pemanfaatan teknologi digital marketing saat ini tidak terbatas hanya untuk kalangan kelas dan golongan kelas tertentu.Dalam kaitannya dengan intellectual capital, tentu digital marketing memiliki peranan yang sangat siginifikan. Sebagai aset perusahaan yang tidak berwujud (intangible), setiap elemen dari intellectual capital harus terus diperhatikan. Entah itu dalam hal human capital, structural capital, maupun relational capital yang ada. Perusahaan saat ini berlomba-lomba memandaikan aset mereka ini dengan digital marketing. Strategi ini terus dipakai untuk keberhasilan jangka panjang perusahaan.

Sementara aktivitas pemasaran yang lain tetap berjalan seperti biasa, strategi-strategi baru terus bermunculan dengan memanfaatkan teknologi dalam dunia digital yang berkembang dengan amat pesat seperti social media integration, mobile marketing, web metrics and analytics, digital campaign management, email marketing, dan lain sebagainya. Ditambah lagi dalam perindustrian hotel yang sebagian besar pelanggannya merupakan tamu dalam rangka berbisnis atau hanya untuk berwisata, mereka pasti sudah sibuk dengan urusannya sendiri. Peran digital marketing sangat diperlukan supaya karyawan sebagai aset perusahaan dapat menangani dan menganggapi kebutuhan pelanggan dengan cepat dan praktis. Maka dari itu, digital marketingdalam industri hotel bintang 4 berperan sangat signifikan pada intellectual capital dalam memandaikan karyawan mereka yang bertujuan untuk kemajuan organisasi dan perusahaan.

Digital Marketing sendiri memiliki nilai path positif terhadap Intellectual Capital sebesar 0,721. Hal ini menunjukkan bahwa Digital Marketing memiliki pengaruh yang kuat dalam membentuk Intellectual Capital dari karyawanhotel bintang 4 di Jawa Timur.

\section{Digital Marketing terhadap Perceived Quality}

Pada hasil penelitian ini dapat dilihat bahwa Digital Marketing tidak hanya memiliki pengaruh pada Intellectual Capital, namun berpengaruh pula pada Perceived Quality dari industri hotel bintang 4 di Jawa Timur dengan nilai uji $T$-statistics $>1,96$ yaitu 15,531. Hasil tersebut membuktikan bahwa Digital Marketing memiliki dampak signifikan bagi kemampuan perusahaan untuk meningkatkan kesan kualitasnya di mata konsumen.

Digital marketing sebagai salah satu teknik promosi yang baik dan efisien, tentu menjadi ancaman serius dalam persaingan yang berada dalam satu industri serupa, terutama dalam industry hotel bintang 4 di Jawa Timur.Media ini dapat membentuk persepsi yang diciptakan kepada konsumen mengenai kualitas dari suatu produk yang ditawarkan oleh para pelaku bisnis. Dapat dikatakan bahwa dalam pengaplikasian Digital Marketing memiliki dampak positif dan berhubungan dengan persepsi yang diciptakan kepada para konsumen.

Dalam pengaplikasian media digital marketing, hal ini sangat berpotensi menciptakan persepi dalam masyarakat mengenai kualitas ataupun performa. Persepsi seperti inilah yang menjadi nilai tambah dan tidak dimiliki oleh pelaku bisnis hotel yang tidak memanfaatkan digital marketing.Ditambah lagi, di era ini yang didominasi oleh generasi yang mengandalkan teknologi dan suka semua yang serba cepat dan instan, maka penciptaan kesan kualitas inilah yang dapat menjadi senjata dalam memberikan nilai yang sebelumnya tidak dimiliki. Persepsi yang tercipta karena adanya digital marketing ini menjadi suatu keuntungan tersendiri dalam jangka waktu yang tidak sedikit.Tentunya hal ini menjadi nilai positif perusahaan dalam menghadapi persaingan yang ada.

Apabila melihat pada nilai path coefficient, hubungan dari Digital Marketing menuju Perceived Quality memiliki nilai sebesar 0,728 yang merupakan hubungan positif. Hal ini berarti keberadaan Digital Marketingdalam industri hotelbintang 4 di Jawa Timur mampu berperan dalam menciptakan kesan kualitas yang baik di mata masyarakat.

\section{Digital Marketing terhadap Organizational Perfor- mance}

Hasil penelitian ini juga menunjukkan bahwa Digital Marketing tidak berpengaruh cukup kuat terhadap Organizational Performance. Pada hasil penelitian ini diketahui bahwa tidak adanya pengaruh kuat tersebut dari hasil uji T-statistics dengan nilai 0,903. Dikatakan tidak cukup kuat karena T-statistics yang dimiliki lebih kecil dari 1,96. Hasil tersebut membuktikan bahwa Digital Marketing tidak memiliki pengaruh signifikan terhadap Organizational Performance. Bila dilihat dari path coefficient, hubungan dari Digital Marketing terhadap Organizational Performance sebesar 0,095. Angka ini jauh lebih kecil daripada hubungan Digital Marketing terhadap Organizational Performance bila melalui Intellectual Capital yaitu sebesar 0,301 $(=0,721 \mathrm{x}$ $0,417)$ dan Perceived Quality $0,255(=0,728 \times 0,350)$.

Digital Marketing industri hotel bintang 4 di Jawa Timur belum mampu secara langsung meningkatkan performa organisasi perusahaan. Hal ini terjadi karena adanya digital marketing yang baik namun tidak diikuti dengan kemampuan sumber daya berupa modal intelektual para karyawan yang mau terus 
belajar dan mengikuti perkembangan zaman, dan juga kurangnya persepsi kualitas yang baik dari mata masyarakat,maka perusahaan tidak mampu meningkatkan Organizational Performance. Maka dari itu pada objek penelitian ini sangat dibutuhkan peran variabel intervening Intellectual Capital dan Perceived Quality untuk menghasilkan Organizational Performance yang baik.

\section{Intellectual Capital terhadap Organizational Per- formance}

Dalam penelitian ini dibuktikan bahwa Digital Marketing yang dimiliki oleh industri hotel bintang 4 di Jawa Timur akan menciptakan Organizational Performance bagi perusahaan dengan nilai uji $T$ statistics $>1,96$ yaitu senilai 5,011 sehingga disimpulkan bahwa Digital Performance berpengaruh pada peningkatan Financial Performance perusahaan.

Tingkat keberhasilan suatu perusahaan ditentukan oleh tingkat kemampuan karyawan dalam mengelola aset dan sumber daya yang dimiliki oleh perusahaan. Apabila perusahaan memiliki karyawan dengan kapabilitas tinggi, kompetensi yang bagus, karyawan yang terpuaskan, kemudian perusahaan memiliki organisasi yang bagus seperti struktur dan proses organisasi yang jelas, maka hal tersebut dapat meningkatkan kinerja bisnis perusahaan.

Selain itu apabila dilihat dari nilai path coefficient, hubungan dari Intellectual Capital menuju Organizational Performance sebesar 0,417, dimana merupakan hubungan yang baik. Nilai ini juga lebih besar jika dibandingkan dengan hubungan langsung antara Digital Marketing dengan Organizational Performance sehingga Intellectual Capital terbukti berperan sebagai variabel intervening. Hal ini mengkonfirmasi bahwa modal intelektual perusahaan yang berupa aset tidak berwujud ini dapat meningkatkan performa dari organisasi atau perusahaan.

\section{Perceived Quality terhadap Organizational Perfor- mance}

Nilai Perceived Quality terhadap Organizational Performance pada industri hotel bintang 4 di Jawa Timur memiliki nilai $t$-Statistic di atas 1,96 , yaitu 3,163. Nilai ini menunjukkan bahwa hubungan antara Perceived Quality dan Organizational Performance memiliki nilai yang signifikan.

Penciptaan kesan kualitas memiliki dampak yang cukup signifikan terhadap performa organisasi. Persepsi yang baik dari suatu perusahaan atau merek tertentu adalah sumber utama keunggulan kompetitif. Oleh karena itu, hal ini merupakan aset strategis yang berharga yang langsung terkait dengan kinerja dan performa dari organisasi perusahaan, yang dalam hal ini adalah industri hotel bintang 4 di Jawa Timur. Dapat disoroti bahwa organisasi mendapatkan keuntungan dari hal yang dirasakan secara positif oleh karyawan dan pelanggan. Sebuah citra perusahaan yang solid dapat akan menjadi sangat menarik dan mereka memiliki persepsi tertentu tentang sebuah organisasi bahkan sebelum mereka mulai berinteraksi secara langsung.

Nilai path coefficient dari Perceived Quality terhadap Organizational Performance adalah 0,350. Nilai ini menunjukkan adanya pengaruh yang cukup kuat dari Perceived Quality terhadap Organizational Performance. Karyawan hotel bintang 4 di Jawa Timurakan terusberusaha untuk meningkatkan kesan kualitas perusahaan di mata masyarakat yang nantinya akan berdampak dalam peningkatan performa perusahaannya.

\section{KESIMPULAN DAN SARAN}

Dari seluruh pembahasandalam penelitian ini, maka dapat disimpulkan bahwa Digital Marketing merupakan hal penting yang harus dimiliki oleh industri hotel bintang empat untuk terus berkembang dan bisa menghadapi persaingan. Hal ini dibuktikan dalam penghitungan statistik bahwa implementasi Digital Marketing berpengaruh positif terdahap Intellectual Capital dan Perceived Quality serta variabel-variabel tersebut yang berperan penting dalam menciptakan Organizational Performance.

Oleh karena itu, industri hotel bintang empat di Jawa Timur harus lebih meningkatkan Digital Marketing agar terciptanya modal intelectual dan kesan kualitas yang baik. Dengan adanya training bagi karyawannya, maka diharapkan tidak ada lagi kesenjangan sehingga penyampaian informasi ke pelanggan dapat terlaksana dengan baik dan hal ini dapat meningkatkan performa organisasi dari perusahaan.

\section{DAFTAR PUSTAKA}

Aaker, D. (2003), "The power of the branded differentiator", Sloan Management Review, Fall, pp. 83-87.

Abdillah, W., \& Hartono, J. (2015). Partial Least Square (PLS) - Alternatif Stuctural Equation Modeling (SEM) dalam Penelitian Bisnis (Cetakan 1). Yogyakarta: Penerbit Andy.

Badan Pusat Statistik, 2017, retrieved on 25 Maret 2017, from source http://www.bps.go.id

Bernardin and Russel, 1993.Human Resource Management. New Jersey: International Editions Upper Saddle River, Prentice Hall 
Bontis, N. (2008). Intellectual capital and business performance in the Portuguese banking industry Maria do Rosário Cabrita, 43, 212-237.

Kim, E. Y., \& Kim, Y. (2011). Predicting online purchase intentions for clothing productsnull. European Journal of Marketing, 38(7), 883-897.

Malhotra, N. K. (2004). Marketing research: an applied orientation (4th Edition). New Jersey: Upper Saddle River.
Malhotra, N.K. (2007). Marketing Research, an Applied Orientation. New Jersey: Pearson Education.

Simanjuntak, Payaman J., Manajemen dan Evaluasi Kinerja. Jakarta: FE UI, 2005.

Stewart, T. (1997) Intellectual Capital: The New Wealth of Organizations,. Nicholas Brealey Publishing, Business Digest, New York.

Sugiyono. (2009). Metode penelitian bisnis : pendekatan kuantitatif, kualitatif, dan $R$ \& $D$ (Cetakan 14). Bandung: Alfabeta. 